\title{
Evolution of Project Management in Integration Development Trends of Today's Russia
}

\author{
Inessa Lukmanova $^{1,{ }^{*}}$ and Natalia Yaskova $^{1}$ \\ ${ }^{1}$ Moscow State University of Civil Engineering,26, Yaroslavskoye shosse, Moscow,129337, Russia
}

\begin{abstract}
Today's development trends are affected by many external and internal factors, stepping up globalization processes, faster innovation cycles, negative effects of various bans, import and export sanctions slapped on some categories of goods, technologies, capital, etc. Tit-for-tat responses of the economic systems seek sustainable development of countries taking part in the integration processes. A radical-yetconstructive strategy that deepens integration can tackle the problem. Its focus is determined by the need to upgrade the economies of the former Soviet Union; while a mutual interest in the rollout of the synergistic integration potential channels common efforts on transcontinental megaprojects. A new type of integration projects creates comprehensive methods of project management. They feature the need for information transparency and controlled alignment of innovation, investment, construction and resource capacities of member countries. With streamlined resource flows, the Eurasian transit will help facilitate and cut costs of commodity exchange among countries, provided they take synchronized efforts in not just technical and technological, but also organizational, economic, legal and IT innovations.
\end{abstract}

\section{Introduction}

The modern history of Russia is full of unexplained, at first glance, phenomena. The hard-line market reforms that radically changed the aspects of ownership and scanned basic market-type regulation institutions, failed to create an effective control mechanism for the sustainable development of the country. Innovations have been adopted and already become normal in the democratic bedrocks of social life, but speaking about the restructuring of the production forces, their performance and today's condition resulted from innovations were far from the benchmarks. The production volumes expressed in comparable prices decreased by more than half vs. the pre-reform level, the engineering standards for manufactured goods declined, the scientific groundwork and exploratory research in the industry segments almost disappeared. Many scientists, politicians and independent experts tried to assess the quality and innovation of products made in Russia before the reforms [1]. As for those who should have benefited from the transformation, i. e., the Russian people, they faced a dilemma: "What is better: empty shelves and the deficit, but the best consumer basket of groceries in the world, or supermarkets filled with

*Corresponding author: lukmanova@mgsu.ru 
unhealthy food, low-quality goods, and stocks in every street corner?" that still remains unanswered. There are many problems and issues concerning market relationships. They are dealt with differently depending on political beliefs, education and cultural preferences. The main thing is that people of all social groups feel dangers of destructive processes taking place in the Russian economy, and this feeling is getting more acute. The lifestyle and life purposes, the formats of meeting personal needs, life standards, success criteria, etc., once accepted almost matter-of-factly, have been successfully "digested" by the Russian cultural and historical environment and are now largely identified as our own. Yet, production relations resulted from borrowed market institutions, mechanisms, norms and rules have actually toppled the existing scientific, technical and production potential. This abysmal state of things has been successfully camouflaged with available, often imposed, imports. Instruments, tools, machines and other basic categories were quickly replaced with imports. Simultaneously, the focus of the national economy on raw materials, in fact, ensured sustainable growth of mechanical engineering and instrument making in supplier countries. The illusion of affordable civilization amenities that could be obtained in exchange of resources has been destroyed by the global recession. The modern political events have exposed fragile business relations between Russia and most industrialized countries. This was manifested in their bans and sanctions slapped not just on the import of high-tech commodities, but also services, technologies and capital.

"The production of production means" that the country was so persistently and consistently obsessed with in its socialist era, but completely neglected in the times of market reforms, returned to the contemporary development agenda. Unfortunately, it was impossible to replace the growing dead capital - abandoned farmlands, closed and idle production sites, capital flight (both in terms of money and brains) with consumer boom even in a well-resourced Russia.

\section{Methods}

The failure of hard-line reforms rolled out on the entire post-Soviet space was manifested not just in significant deformation of expectations, but also in the fall of business activity in almost all economy sectors. The rise expected in free market conditions turned into a sharp decline except for export-oriented industries. Moreover, it became obvious that market institutions clearly failed to cope with the persisting destructive processes that gained momentum in the consumer sectors, mechanical engineering, advanced processing industries, production of production means, etc. Technology breakthroughs and emerging development trends did not have support and were too slow to fit in the economic management practices [2].

Thus, vague theories, promises and upbeat expectations were not enough to overcome the growing industrial lag. This required the target rethinking of industrial policies reflected in the concept of priority measures in the socio-economic development of the Russian Federation, the key activities of the Government of the Russian Federation until 2018, the strategy of the socio-economic development of the Russian Federation until 2030, materials for the Security Council of the Russian Federation "Measures of Import Substitution in Civil Industries for the National Security amidst Aggravated International Climate", strategies for the growth of the Russian consumer goods industry up to 2030, documents of the Presidential working group of the Economic Council of the Russian Federation on "Priorities of Structural Reforms and Sustainable Economic Growth", etc. [3]. Their overall target can be described as the reorganization of production growth potential based on industrialization focused on exports and import substitution. The latter is based on import substitution for investment purposes and encouraging involvement of Russian producers in global added-value chains. Driven by the increasing pressure of transnational capital that 
scarcely ever adheres to the market principles of free competition, the project pool supporting the Eurasian integration of Russia, Kazakhstan and other CIS countries is becoming a prerequisite for competitiveness at global scale. Overcoming imbalances of the world economy, in fact, means dealing with the true causes of the global crisis. For Russia, this means a qualitative transition to the unquestionable rollout of transcontinental Eurasian integration projects [4]. This approach is fully consistent with the generally accepted concepts of the third industrial revolution. Its key distinguishing feature is the shift of added value from manufacturing industries to engineering and project financing. These circumstances require a truly new large-scale approach. Its innovation lies in the creation of a whole conglomerate of new industrialists in artificial intelligence based on serviceoriented engineering, where "smart machines" will not just deal with the production at all coherent production stages of goods and services, but also identify needs. Therefore, a crucial driver of economic and industrial growth, as well as competitive production, will be a science-based industry with its inherent group of high-tech industries. This will require structural transformation of each and every reproduction process. Complex, sometimes chaotic links of structures and tiers require modification even with traditional partnerships. Here, a number of components will have to be substituted with more efficient counterparts, some should be re-created and some outsourced, etc. Anyway, project management tools must be modified to fit the new scale and development goals [5].

Let us research the evolution of project management using the example of infrastructure megaprojects in the expanded Eurasian format of the international Silk Road Economic Belt and the context of the agreement on cooperation of the Eurasian Economic Union (EEU) and the Silk Road Economic Belt [6]. The startup phase of such radical-yetconstructive strategy for post-crisis development amidst the deepening of the interstate integration in the CIS space requires the rollout of infrastructure megaprojects able to connect adjacent Eurasian countries, ensure aligned operations of strategic alliances, vertically integrated corporations and holding companies at the interstate economic level. The research conducted by the authors [7] shows that the consolidation of production and economic opportunities of the largest entities subject to structural transformations in the promising industrial segments will increase the innovation and investment potential of all reproduction processes, including their start and final phases. A special place in project management and promotion of integration processes is taken by Silk Road Economic Belt construction project [8]. It is based on the creation of adequate conditions for industrial cooperation in multilateral, regional and global formats for the rollout of large-scale transcontinental megaprojects ensuring reciprocal multilateral flows of resources and commodities in a barrier-free environment. The target project breakdown helps to identify key priorities:

- expand cooperation in commerce and investments, cultivate new economic growth factors and employment drivers;

- promote facilitation of mutual investments and growth of industrial cooperation, roll out major joint investment projects, joint development of tech parks and cross-border economic cooperation zones;

- enlarge transport infrastructure and intermodal transportation;

- create mechanisms to facilitate commerce and ensure harmonization of rules and regulations in the free trade zone between the EEU and China;

- promote payments in national currencies in commerce, direct investment and lending, creation of currency swaps, deepen cooperation in export lending, insurance, project and trade financing, bank cards [9].

Special importance is attached to the strengthening of cooperation among various financial institutions, such as:

- Silk Road Fund, 
- Asian Infrastructure Investment Bank,

- The Shanghai Cooperation Organization Interbank Consortium, etc.

\section{Results}

The EEU and China are actively enlarging dialogue mechanisms to align the Eurasian economic integration and construction of the Silk Road Economic Belt. The dialogue covers all issues of interaction in order to reform the common Eurasian space.

The review of measures on many forums (the APEC summit, the UN assemblies and conferences, parliamentary sessions of the Republic of Kazakhstan, hearings in the Russian State Duma, international forums and conferences) has shown that isolated additions to project management methodology are not enough. Even special-purpose institutions like interbank associations or trust funds are not sufficient as the scale of today's integration tasks and megaprojects requires not just streamlined investment processes, launch of innovative renewal and upgrade mechanisms, substitution and front-running technologies, etc., but also data support, organization and economic mechanisms, monitoring and distribution of up-to-date, smart management rules and practices. The fusion of a vast array of tasks, according to the authors, should be carried out in the format of complex alignment technologies subject to immediate development and rollout. These technologies are particularly essential for the target synchronization of the construction process. Each member country, for example, can build low-power logistics centers fulfilling the innovative potential of stock expansion and amplifying flows of resources amidst the effective integration in view of the synergistic potential of the international labor division and production expertise of member countries. But integration will fail without comprehensive resource distribution hubs on key transport routes supported by geo information platforms and the use of state-of-the-art equipment and technologies scaled to meet overall target needs. A new type of project tasks - alignment of tasks, resources, participants with localization in space and time and control of operations by national development institutes - requires systemic research at the theoretical, methodological, methodical and executive levels. Putting aside the underlying political causes, the business environment must be prepared to restructure the organizational and economic activity formats on an ongoing basis.

At the summit in the context of the $70^{\text {th }}$ session of the UN General Assembly (November 27, 2015), the President of the Republic of Kazakhstan N. A. Nazarbayev highlighted the importance of the Big Eurasian megaproject able to become the largest integration project of the XXI century and bringing together the Eurasian Economic Union, the Silk Road Economic Belt and the European Union. This Project revives the present-day economy of the Silk Road, opens up opportunities to reduce the transit route from the AsiaPacific Region (APR) to Europe, establish association of the APR with Europe and the Middle East. This entails large-scale mutually agreed reconstruction of infrastructure by countries, creation of new transport routes by land, sea and air. Furthermore, the above project involves restructuring of energy supply. With regard to energy, we can note that the connection of different time zones will help to maneuver the production of electric power, balance load peaks, ensure stable power supply, etc. To some extent, a unified power system of the USSR is being reproduced at a new upper level with high-tech and transcontinental routes able to save time and costs of transportation. Within the framework of the Silk Road Economic Belt, three basic transit routes from China to the EU are tested. The first is a multimodal route via Kazakhstan and Russia, the second is a railway route via Mongolia and Russia, the third lies via Pakistan from Kashgar (China) to the port of Gwadar (Pakistan). 
As you know, China announced its initiative to create the international Silk Road Economic Belt voiced by the President Xi Jinping at Nazarbayev University in 2013. In November 2014, China established an investment fund of $\$ 40 \mathrm{bn}$ to be invested in projects of the Silk Road land and sea routes [1]. In this regard, China is actively developing cooperation with the countries of the Eurasian Economic Union. Thus, the joint meeting of Russia and China, as mentioned, resulted in an agreement on cooperation of the Eurasian Economic Union (EEU) with the Silk Road Economic Belt [1]. It is assumed that the initial phase will involve 20 countries with the aggregate global GDP share $25 \%$. The Silk Road Economic Belt means a transit route of goods and services, large-scale investment cooperation and establishment of new businesses. In this respect, the stakeholders work on an agreement with China to construct diversified production facilities invested by China.

It is important to note that the rollout of the Silk Road Economic Belt investment and construction project entails cooperation of a number of countries in the Central Asia, the Middle East and the EU. No doubt, formats and methods of the Silk Road cooperation should take into account not only the interests of China, but also Kazakhstan, Russia, Central Asia, Iran, Pakistan, etc. In this aspect, further deepening of interaction and integration formats among countries and regions is fairly necessary. At the $8^{\text {th }}$ Astana Economic Forum, the President N. A. Nazarbayev offered to create the joint Eurasian economic space. "It is crucial for us to adopt common rules taking into account the national interests of all members and yet with the aim to remove barriers and improve win-win integration...". Thus, it entails registration of new trends in the integration processes of the EEU countries - members of the transcontinental project. The Joint Eurasian Economic Space (JEES) restructures not just transport routes and investment areas, but also encourage new production sites as part of the upgrade engaging concerned countries and their capitals on the basis of joint entrepreneurship.

\section{Discussion}

Today, the Eurasian transit takes place via Kazakhstan and Russia by land. In order to make it competitive with the southern sea route through the Suez Canal, Russia and Kazakhstan should increase the water transport transit possible with Eurasia canal [9]. The Asian Infrastructure Investment Bank together with Kazakhstan, Russia and China will help to provide funding for its construction on win-win terms. Today, scientists from Kazakhstan, Russia and the Chinese corporation Sinohydro deal with complex feasibility study of real conditions and prospects of Eurasia canal project.

As part of Russia's and Kazakhstan's integration in order to create a transport route New Silk Road, as well as increase infrastructure capacities in Moscow and Moscow region, a new construction project was launched in Domodedovo, Moscow region: the Central Dry Port will feature a full cycle of handling containerized cargo. Its unique location will reduce traffic on highways in Moscow and the region. The Central Dry Port will have a container and customs terminals, empty container depot, terminals for refrigerated containers, as well as low temperature and dry warehouses. The total investments are estimated at $\$ 169 \mathrm{mln}$, the planned payback period will take ten years. In addition to the shareholders' funds, it is planned to attract loans. The competitive advantage of the project is its own railway container terminal along with the access to M-4 Don highway. Of course, such infrastructure projects should be replicated, serving for the transit potential of Russia and complementing the power of megaprojects. The construction of resource distribution hubs will create a solid foundation for the rollout of integration ideas and assist freight transportation to the global market and transport of goods from China, India, Russia and the republics of the Central Asia, the European Union in a cost-effective way. 


\section{Conclusion}

The global scale of tasks is impressive. Meanwhile, megaprojects are bringing together the best talents of the tech world. For example, the transition to a low-carbon economy has triggered innovative projects of wind farms, and projects focused on renewable energy sources are underway (a wind power station in Yereymentau, on Shelek route, etc.). Yet, the restructuring of the carbon market, regulatory, legal and information support as crucial parts of project management are still beyond scientific search. Long-term research and hands-on experience of the authors have shown that unaligned economic interests of all hierarchical levels and participants can doom any project. A process of alignment cannot refer just to the financial relationships among parties. Moreover, the IT system helping to develop and roll out megaprojects with controlled financial liabilities should be an integral condition of new generation projects. In this regard, it is communicative information platforms that should ensure parity, transparency and team approach in project solving global problems. An example here is the communication platform G-Global serving as a virtual forum. Since the launch of the project, it has brought together representatives of 160 countries of the world. This virtual platform was home for total 68 online conferences, received more than 110 feedback comments for the G20 leaders, including some 700 reports, 80 recommendations for the AEF and proposals for the conference. The UK MP Mr. Brennan expressed his opinion in connection with the growing global popularity of the communication platform G-Clobal: "The concept of G-Clobal is a model of the XXI century's thinking" [7]. This is also an opportunity to increase the integration potential of Eurasianism.

On the threshold of Astana's EXPO-2017 under the slogan "Energy of the Future", it is crucial to use a common platform to bring together scientists and experts of the international community in order to develop common rollout principles for transcontinental projects able to strengthen the supporting structures of modern formats and integration models of sustainable development.

\section{References}

1. S.Y. Glazev, Naukaipraktika. 1(9), 41-49 (2013)

2. URL: http://econ.sabanciuniv.edu/dixit (2016)

3. A.A. Pastuhova, Y.I. Nikonova, Mezhdunarodnyjstudencheskijnauchnyjvestnik. 4-3. 476-477 (2015)

4. N.Y. Yaskova, Economikastroitelstva, 3(21), 49-59 (2013)

5. A.T. Spicyn, Novaya industrializaciyaehkonomikiiperspektivyevrazijskojintegracii, realizaciitranskontinental'nyhmegaproektov XXI, Prospekt, Moscow (2016)

6. N.Y. Yaskova, Nedvizhimost, ehkonomika, upravlenie, 1-2, 52-61 (2014)

7. R. Lee, A. Lukin, Russia's Far East: New Dynamics in Asia Pacific and Beyond, Boulder, Colorado (2016)

8. URL : http://thediplomat.com/the-beijing-apec-summit-in-review (2016)

9. I.G. Lukmanova, N.Y. Yaskova, Economikastroitelstva, 5, 13 (2014) 